\title{
The Consequences And Public Policy Implications Of Welfare Reform: A Cost-Benefit Analysis Of The Welfare Reform Policy
}

\author{
Michael O. Adams, Texas Southern University
}

Gbolahan S. Osho, Prairie View A \& M University

Crystal D. Hadnott, Texas Southern University

\begin{abstract}
Welfare reform has been the recurrent subject of heated debate in the United States, culminating in far-reaching legislation in 1996. Taking the measure of that legislation requires attention both to the broader context of which welfare policy is a part and to the merits of the 1996 law itself. Ultimately, the success or failure of welfare reform, which evoked a great deal of partisan rhetoric, will be assessed on empirical rather than partisan grounds. It cannot be determined merely by changes in the size of welfare caseloads. It is crucial to any piece of legislation to analyze the cost in relations to its benefits. Most importantly, we must ask: What has happened to the families and children who have left the welfare system? Personal Responsibility and Work Opportunity Reconciliation Act of 1996 is a successful legislation that needs a little troubleshooting, so it will not be the failed anti-poverty prescription
\end{abstract}

A billion dollars every week for Iraq, $\$ 87$ billion for Iraq. We can't get \$5 billion for childcare over five years in welfare reform. -Jim Wallis

\section{INTRODUCTION}

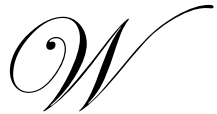

elfare is refers to an assortment of governmental programs that grant assistance to individuals in need to enable them to maintain a minimum standard of well-being, which provides monetary assistance for the basic needs of individuals/families who have exhausted all other avenues of financial support. Access to these provisions is usually granted on the basis of provable need, rather than simple lack of ability to pay for them. These services are often provided free of charge or at a nominal fee with the state and thus ultimately the taxpayers - being liable for the majority of the cost.

Welfare reform is the terminology for a policy modification in the social welfare system to minimize dependence on welfare while establishing self-sufficiency. The reasons for instituting welfare reform usually include objections to the cost of social welfare, the desire to minimize the culture of poverty fostered by the welfare system, negative perceptions concerning the behavior of people who receive welfare, as well as the perceived lack of incentive for welfare recipients to search for employment.

The history of welfare programs in the United States began with Franklin D. Roosevelt Administration's War on Poverty campaign in response to the Great Depression. The key welfare programs of the Great Depression in the United States for individuals involved the Workers Projects Administration (WPA) and the Civilian Conservation Corps (CCC). During World War II, these programs were eliminated when individuals gained full employment. In spite of this, the state government continued to provide welfare for individuals who were not capable of working. After the War on Poverty in the 1960s, welfare recipients increased rapidly with the addition of 
the Aid to Families with Dependent Children (AFDC) program. By the 1980s, controversy engulfed the program, and it drew heavy criticism from all levels of government.

During his first State of the Union Address, President William Clinton promised to "end welfare as we know it" and in August of 1996, Congress passed and President Clinton signed a welfare reform bill, Personal Responsibility and Work Opportunity Reconciliation Act of 1996 (PRWORA). ${ }^{1}$ PRWORA was recognized as the fundamental shift in both the method and the objective of federal cash assistance to the underprivileged. The federal law established Temporary Assistance for Needy Families (TANF), which replaced AFDC and Job Opportunities and Basic Skills Training (JOBS) programs.

Last year, Congress began the process of reauthorizing the historic, bipartisan 1996 welfare reform law. According to the Department of Health and Human Services, welfare reform helped to move 4.7 million Americans from welfare dependency to self-sufficiency within three years of enactment, and the number of welfare caseloads has declined by 54 percent since 1996. The 1996 welfare reform law expired at the end of last year. President Bush is calling on Congress to act now to sustain and expand on the success of welfare reform, in order to strengthen families and help more recipients of welfare work toward independence and self-reliance.

President Bush proposes to make welfare even more focused on the well-being of children and supportive of families. The President's plan is designed to strengthen families and help more welfare recipients work toward independence and self-reliance. The President's welfare reform plan will help more welfare recipients achieve independence through work. The President's plan requires welfare recipients to work 40 hours per week - either at a job or in programs designed to help them achieve independence. Secondly, the plan will increase the welfare-towork resources available for families - The President's plan will provide an average of $\$ 16,000$ per family in federal and state welfare, childcare, and job training resources, compared to $\$ 7,000$ per family available in 1996 when welfare reform was enacted. Although welfare caseloads have declined by more than half, President Bush proposes to fund the Temporary Assistance to Needy Families programs at the fully authorized level of $\$ 17$ billion to ensure that struggling families get the support they need to move from welfare dependency to work and self-sufficiency. In addition, the plan will protect children and strengthen families. The President proposes to continue historically high levels of support for childcare ( $\$ 4.8$ billion per year) through the Child Care and Development Fund. The President's welfare reform plan also provides states financial incentives to give more of the past-due child support payments they collect to mothers and children. The plan will also empower states to seek new and innovative solutions to help welfare recipients achieve independence. The President's plan establishes a Ticket to Independence program to encourage state and local innovation. Under the President's plan, state and local governments will be able to consolidate a range of welfare programs (such as food stamps, housing, workforce programs, and adult education) to eliminate conflicting requirements, reduce red tape and improve their effectiveness for the people they serve. This new flexibility will help states design better programs that could significantly improve service delivery for Americans in need.

Welfare reform has been the recurrent subject of heated debate in the United States, culminating in farreaching legislation in 1996. Taking the measure of that legislation requires attention both to the broader context of which welfare policy is a part and to the merits of the 1996 law itself.

Research exposes the effects of policy as well as becomes an instrument for quantifying and qualifying results. In evaluating the welfare reform policy, there are comprehensive questions this research will answer: 1) what is the nature of the policy in its most primitive state; 2) what effect has it had on the targeted population; 3 ) how do we measure the success of the legislation; and 4) what is the direct cost associated with the success of the policy as well as how does it directly relate to the economic status and stability of our nation's future. Before attempting to measure the successes of the welfare reform legislation, it would be essential to investigate in detail the programs as well as the costs associated with those programs. The purpose of this research is to synthesize progressive assessment on the effects of welfare reform juxtaposed to the federal budget. Ultimately, the success or

\footnotetext{
${ }^{1}$ Personal Responsibility and Work Opportunity Reconciliation Act of 1996, Pub. L. No. 104-193, 110 Stat. 2105 (1996) (codified as amended primarily in scattered sections of 42 U.S.C.).
} 
failure of welfare reform, which evoked a great deal of partisan rhetoric, will be assessed on empirical rather than partisan grounds. It cannot be determined merely by changes in the size of welfare caseloads. Most important, we must ask: What has happened to the families and children who have left the welfare system? In order to understand the impact of welfare reform, researchers, analysts and the public must look at many various outcomes which may indicate changes in family and child well being. The true impact of welfare reform will only be understood when many such indicators are taken into account.

\section{LITERATURE REVIEW}

The desire of President Clinton to "end welfare as we know it" initially was seen as an idea that could never mature into reality with a conservative Congress in office. Matthewson (1996) argued that social problems related to the most disadvantaged citizens require service delivery that is universal, focused, and of reasonable quality. He contended that resource distribution, which makes the delivery of these services possible, is dependent on decision-making structures that pattern relationships between major stakeholder groups, but missing in the debate over welfare reform is a discussion of the decision structures that determine the manner in which policies are formulated, enacted, and implemented. In 1996, much of the debate over the choice between markets and bureaucracy was misconceived. Matthewson concluded that such decision structures are not polar opposites but can work together to provide innovative delivery methods. His research compared evidence from two different political systems: the United States and France. Both countries faced political opposition to welfare policies and both attempted to counter with administrative and political reforms. In his investigation, he probed the differences in those systems and their alternative reforms as well as made some generalizations about political and administrative decision making and the delivery of remedial services to the most disadvantaged citizens in modern democracies, which concluded that in any society this welfare reform template adopted by the two countries would be successful, but there are backlashes from the welfare reform programs, which have to be addressed in the aftermath in order to eliminate all deficiencies as well as criticism.

One of the primary components of the PRWORA legislation is the focus on work requirements and, to a lesser extent, enrollment in an approved training or educational program. More specifically, states have created welfare policies that have stressed quick entry into the paid labor market. As a direct result, there has been a decrease in the number of families receiving cash assistance since welfare reform. According to Bavier (2002), the number of families receiving welfare fell by 56 percent between 1994 and 2000.

There is tremendous interest in understanding the impact of welfare reform, but not much is discussed about how it affected the health care coverage of women and children. Crawley (2005) utilized the Survey of Income and Program Participation, matching type of insurance coverage to the presence of waivers from AFDC or TANF implementation in each state in specific months. Specifically, he estimate the difference before and after welfare reform in the insurance coverage of women and children who were likely to be eligible for welfare compared to those who were likely to be ineligible for welfare. Crawley found that AFDC waivers prior to 1996 and the implementation of TANF after 1996 raised the probability that welfare-eligible women lacked health insurance coverage. Specifically, TANF implementation is associated with a 7.8 percent increase in the probability that a welfare-eligible woman was uninsured. Welfare reform had less of an impact on the health insurance coverage of children. Crawley concluded that there is no evidence that AFDC waivers increased the probability that welfare-eligible children were uninsured. However, TANF implementation was associated with a 2.8 percent increase in the probability that a welfare-eligible child lacked health insurance.

Welfare reform also had an unintended impact on the Medicaid enrollment of eligible immigrants. As a part of welfare reform, Congress barred legal immigrants who entered the United States after August 1996 from Medicaid for five years after immigration. Kandula, Grogan, Colleen, Rathouz and Lauderdale (2004) compared the Medicaid enrollment of U.S.-born citizens to pre-1996 immigrants, before and after welfare reform to determine if variation in state Medicaid policies toward post-1996 immigrants modified the effects of welfare reform on pre1996 immigrants. Before welfare reform, pre-1996 immigrants were less likely to enroll in Medicaid than the U.S.born. After welfare reform, pre-1996 immigrants were even less likely to enroll in Medicaid. The proportion of immigrants in Medicaid dropped 3 percentage points after 1996. For the U.S.-born it dropped 1.6 percentage points, 
except for California, state variation in Medicaid policy toward post-1996 immigrants did modify the effect of welfare reform on pre-1996 immigrants. Kandula et. al. concluded that the federal laws limiting the Medicaid eligibility of specific subgroups of immigrants appear to have had unintended consequences on Medicaid enrollment in the larger, still eligible immigrant community and inclusive state policies may overcome this effect.

Another important question surrounding welfare reform is "what has happened to the earnings and incomes of families who were receiving public assistance when the new policies took effect?" Connolly and Marston (2002) addressed this question by examining the impacts of welfare reform policies on the earnings and income of welfare recipients and nonrecipients. Using a detailed nationally representative longitudinal data set (the Survey of Program Dynamics) covering the period from 1992 through 1997, they found that welfare reform policies do not affect the family earnings of welfare recipients within the first year, but do have a positive effect in the following year. The effect on total family incomes is mixed in the first year. The overall effect is negative, but work-related reforms have a positive effect. All effects on family incomes are insignificant in the following year.

Although there have been a few negative impacts with welfare reforms, there have been a number of successes. One little-known fact is that we have made gains against poverty in recent decades - and welfare reform deserves some credit. The poverty rate among blacks has fallen sharply, though it's still discouragingly high. From 1968 to 1994 it barely budged, averaging 32.4 percent. By 2000 it was 22.5 percent. (The poverty rate is the share of people living below the government's poverty line, about $\$ 19,500$ for a family of four in 2004.) Similarly, there have been big drops in child poverty. Since 1989 the number of children in poverty has fallen 12 percent for nonHispanic whites and 14 percent for African Americans. The economic boom of the 1990s explains much of this improvement. But it is not the whole explanation, because even after the 2001 recession, many poverty rates stayed well below previous levels. For all African Americans, it was 24.7 percent in 2004 . $^{2}$

Lichter and Jayakody (2002) shifted the debate from the current preoccupation with declining caseloads to one focused on the social and economic well-being of fragile families, single mothers, and children. The welfare research revealed many positive changes: reduced poverty rates, lower out-of-wedlock childbearing, greater family stability, and little indication of more spouse abuse or child neglect.

\section{DATA ANALYSIS}

In the years since welfare was reformed to incorporate work requirements, TANF caseloads have been cut in half, and increases in employment rates of disadvantaged, single parents have ranged from 50 percent to 100 percent (see Table 1). According to the United States Department of Health and Human Services, TANF has been a tremendous Federal-State partnership success. Congress established a clear expectation that cash assistance should be temporary and adult recipients should be expected to work and pursue self-sufficiency. At the same time States were given a great deal of flexibility to reform their welfare programs to achieve these goals. As a result, millions of families have been able to end their dependency on welfare and achieve self-sufficiency. TANF caseloads have declined for the sixth straight year. The number of persons receiving TANF cash assistance in September 2002 was 4,995,719 - - a decline of 6.2 during the fiscal year, and a decline of 59.2 percent since August of 1996 when the TANF law went into effect. Families receiving TANF benefits declined 3.9 percent during fiscal year 2002 to 2,024,691. Overall, since the TANF legislation was passed in August of 1996, the number of families receiving TANF assistance has dropped by 54.1 percent. Indeed, our recent experience confirms that the 1996 law has fundamentally changed the way welfare works in America. While we are understandably concerned about job opportunities for recipients, recent data demonstrates that, despite the rise in unemployment during the recent recession, TANF caseloads have not increased as early critics of welfare reform had anticipated. In fact, from March 2001, when the recession began, until September 2002, caseloads declined 4 percent for families and 8 percent for recipients. Welfare programs grounded in expectations of work and focused on helping clients find employment can help families tremendously even when economic opportunities appear to be less available.

\footnotetext{
${ }^{2}$ Newsweek - Business Section (Aug. 7, 2006) "One Reform that Worked"
} 
Table 1: Total TANF families and recipients (in thousands)

\begin{tabular}{|c|c|c|c|c|c|c|c|c|c|}
\hline & Jan-93 & Jan-94 & Jan-95 & Jan-96 & Jan-97 & Jan-98 & Jan-99 & Jun-00 & $\begin{array}{l}\text { Percent } \\
(93-00)\end{array}$ \\
\hline Families & 4,963 & 5,053 & 4,963 & 4,628 & 4,114 & 3,305 & 2,734 & 2,208 & $-56 \%$ \\
\hline Recipients & 14,115 & 14,276 & 13,931 & $\begin{array}{r}2,755,000 \\
12,877 \\
8,334,000\end{array}$ & $\begin{array}{c}\text { er famili } \\
11,423 \\
\text { r recipie }\end{array}$ & 9,132 & 7,455 & 5,781 & $-59 \%$ \\
\hline
\end{tabular}

Source: U.S. Dept. of Health \& Human Services Administration for Children and Families

The national TANF caseload fell slightly during Fiscal Year (FY) 2002, continuing its long-term decline since the program's creation. Figure A shows the average number of families receiving benefits from 1960 through 2002 and the precipitous reduction that began in the mid-1990's and continues today (see Figure A).

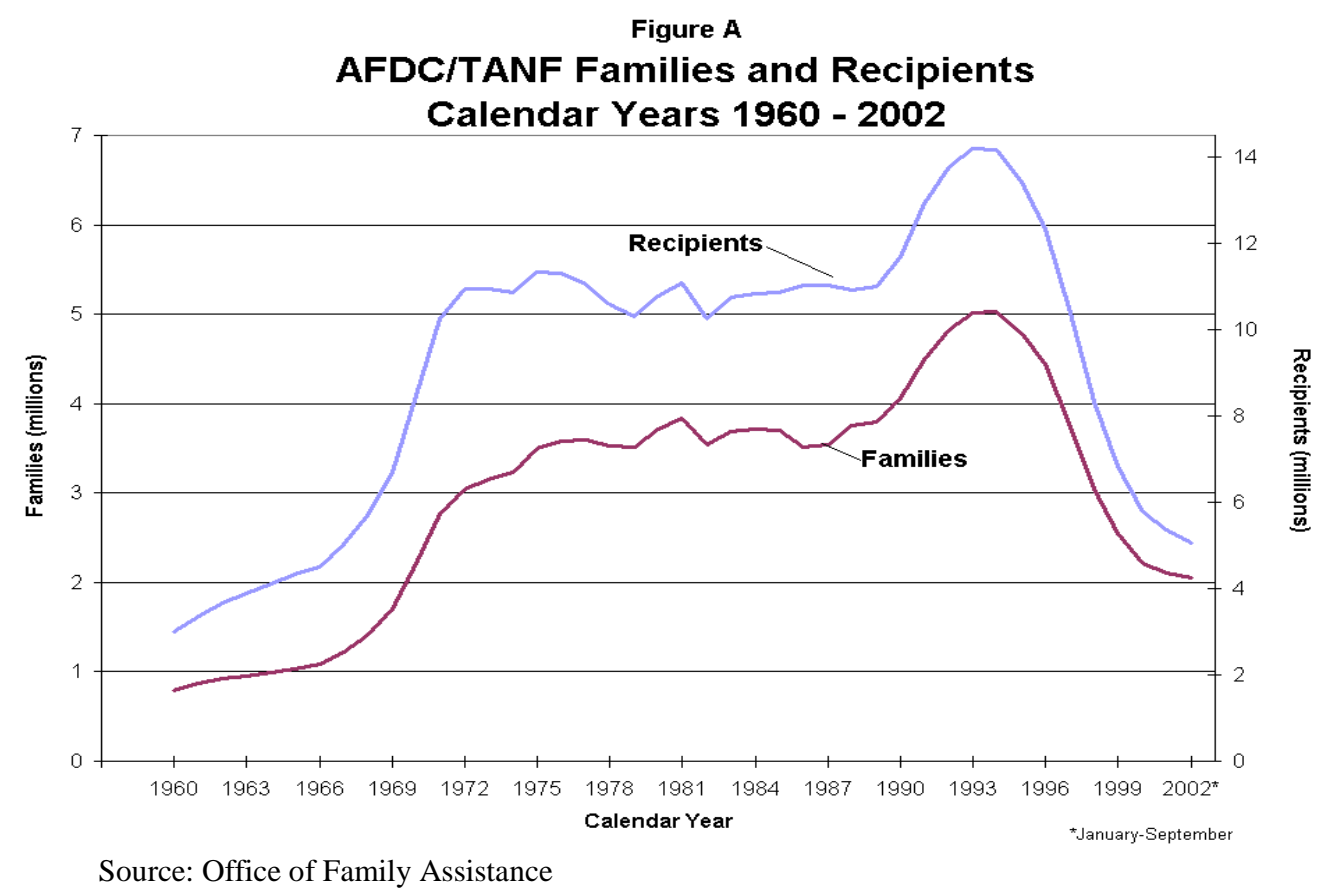

Compared with recent years, however, the caseload decline during FY 2002 was very modest. A total of 2,029,751 families in states, territories, and tribes were aided in September 2002, the last month of the fiscal year. Excluding Tribal TANF families (counts for which are incomplete), 73,413 fewer families received cash aid than at the end of FY 2001, representing a 3.5 percent decline in State and Territory TANF cases over the year. Figure B shows the number of families that received assistance each month in FYs 2000 through 2002. 


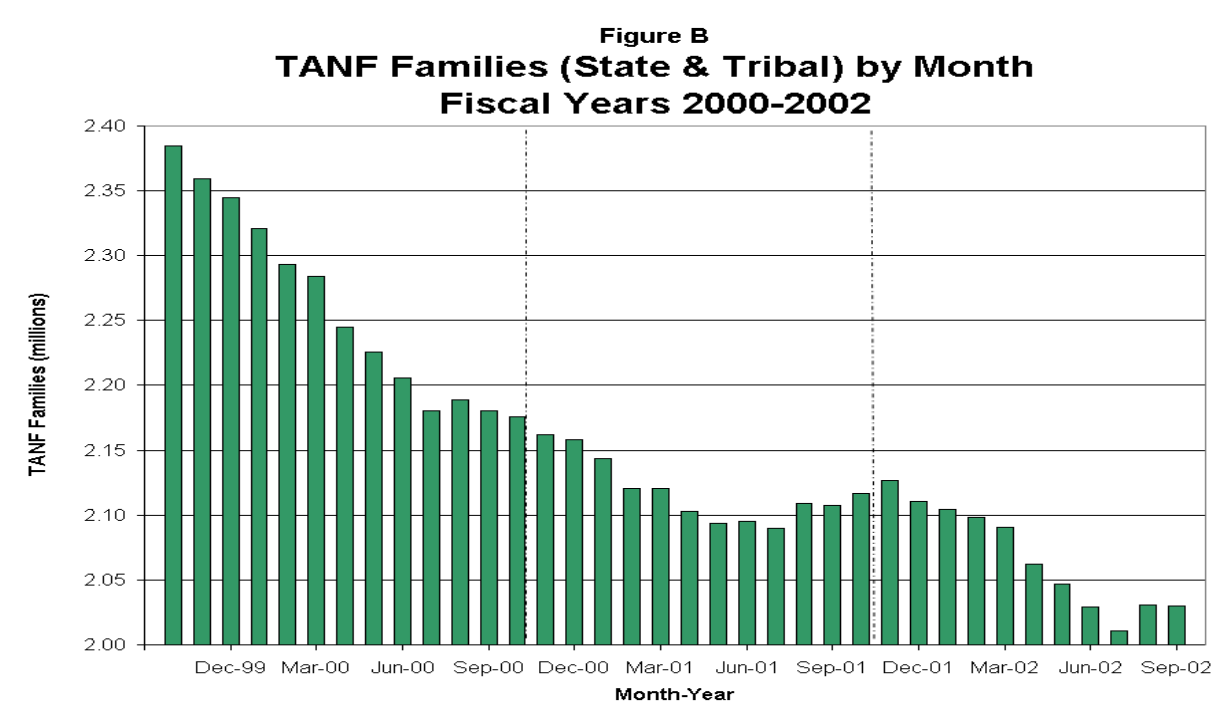

Source: Office of Family Assistance

Tribal TANF programs, for example, are serving an increasing proportion of the national TANF caseload. It is anticipated that many additional Tribes will elect to operate their own programs in the future. Figure C shows the number of families that received assistance under Separate State Programs (SSP) each month in FYs 2000 through 2002. Some states are serving families through SSPs who have exhausted their time-limited Federal TANF benefits, and as time limits have begun to impact in nearly every state it is helpful to consider TANF and SSP case trends together. The jump in SSP families at the beginning of FY 2002 is due primarily to the fact that New York and a few other states have moved families that are reaching their Federal time limit to SSPs. Figure D illustrates the combined TANF and SSP caseload over the past three years. Despite the shift of time-limited cases, note that the combined caseload of both programs still declined slightly in FY 2002. TANF is also used to provide services to many families not receiving cash aid (e.g., employed families receiving child care and transportation only), but for whom states do not report case counts.

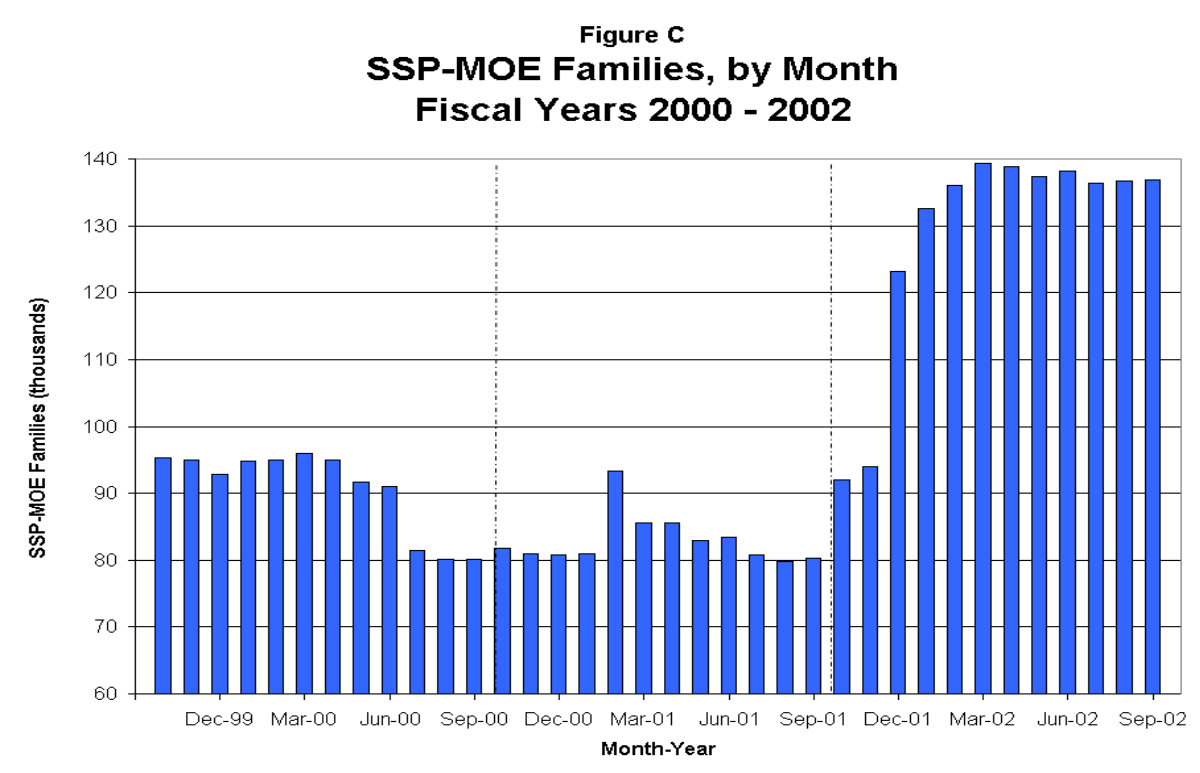

Source: Office of Family Assistance 


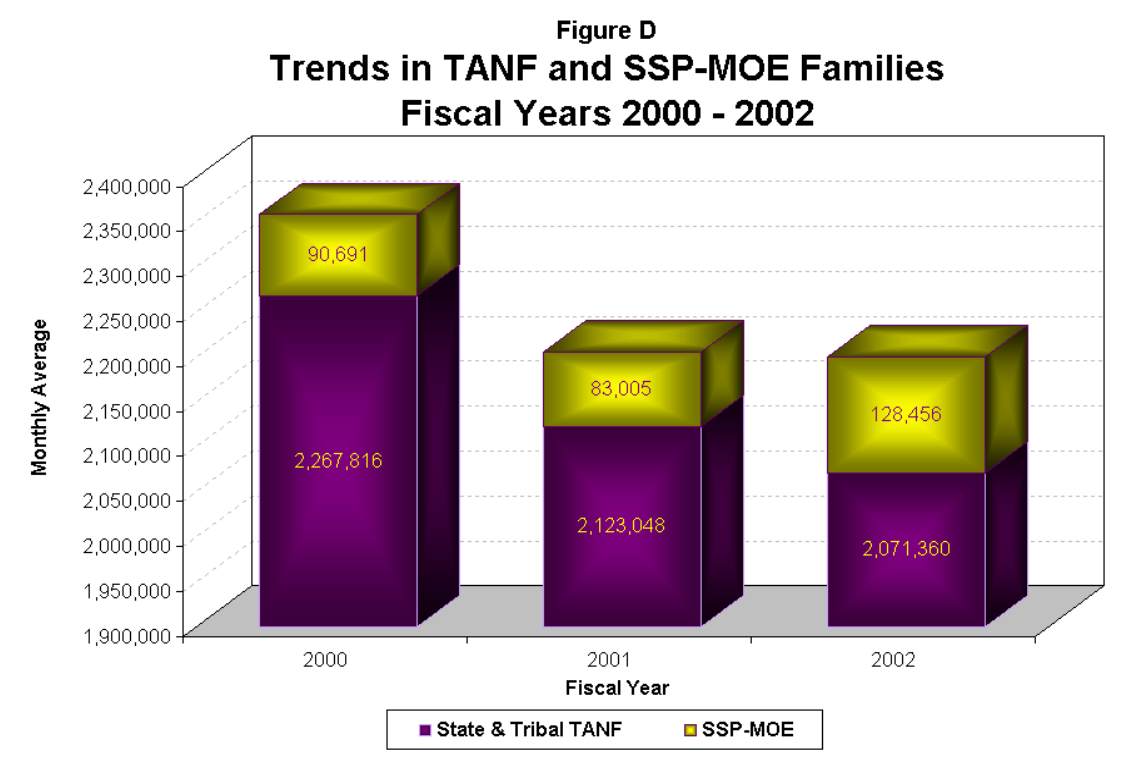

Source: Office of Family Assistance

Chart 1 represents a portion of the Health and Human Services (HHS) budget. There are six slices. The first slice, in blue, is labeled Medicare with 55.5 percent of the budget. The next slice is red and labeled Medicaid representing 28.6 percent of the budget. The third slice for Other Mandatory Programs is black and represents 0.4 percent of the budget. TANF is a light blue slice representing 2.5 percent of the budget. Children's Entitlement Programs consume 2.9 percent of the budget, the slice is orange. Finally, the sixth slice is yellow and represents the Discretionary Programs which make up 10.1 percent of the total HHS budget. HHS fiscal year (FY) 2007 Budget supports the Department's mission to provide for the health, safety, and well-being of Americans. FY 2007 outlays will total $\$ 698$ billion, an increase of $\$ 58$ billion over FY 2006. Consistent with the President's long-term goal to cut the deficit in half by FY 2009, the HHS budget includes both new mandatory savings proposals and a reduction in discretionary spending. The FY 2007 HHS budget totals $\$ 74$ billion in discretionary program level, a decline of $\$ 1.5$ billion. In discretionary budget authority, excluding emergency funding, the total is $\$ 66.0$ billion, a reduction of $\$ 1.4$ billion. The benefits of welfare reform far exceeds the cost to accomplish the objectives outlined in the mission.

Chart 1: FY 2007 the U.S. Department of Health and Human Services Budget

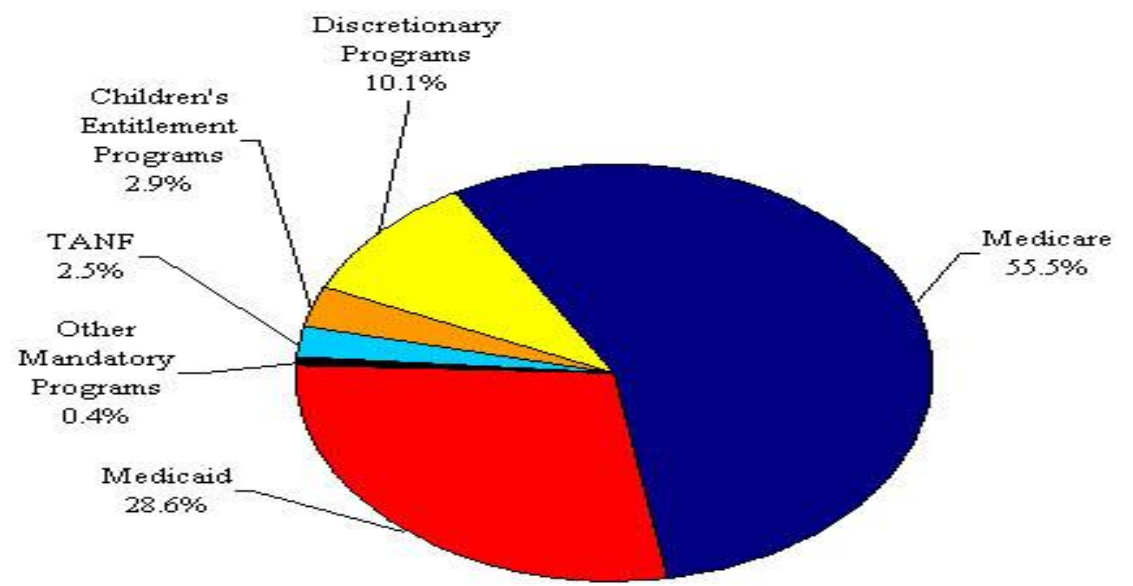

Source: U.S. Department of Health and Human Services 


\section{RESULTS AND RECOMMENDATIONS}

Although welfare reform has been extremely successful, there are a various barriers and underlying conditions that exist in the current welfare reform legislation. Welfare and other support programs should extend outreach efforts to ensure that low-income families who are no longer, or who never have been, on welfare receive the support and services they need until they earn sufficient income to provide an adequate standard of living for their families. If work is the more important goal of the legislation, further efforts are needed at the federal, state, and local levels to expand child care subsidy programs for working poor families, and to strengthen the supply of high-quality child care and after-school options in low-income neighborhoods (within a six blocks radius of residences). Welfare programs should also expand their goals to include reducing poverty and promoting family economic self-sufficiency and child well-being. Job retention and advancement services for low-income families should be one of the strategies in support of this goal, and incentives should be provided to encourage development of more effective programs. Another strategy could be the development of a family self-sufficiency program which models the Department of Housing and Urban Development's program. The Family Self-Sufficiency Program (FSS) is a HUD program that encourages communities to develop local strategies to help voucher families obtain employment that will lead to economic independence and self-sufficiency.

Public housing agencies (PHAs) work with welfare agencies, schools, businesses, and other local partners to develop a comprehensive program that gives participating FSS family members the skills and experience to enable them to obtain employment that pays a living wage. A separate program, the public housing FSS program, is available for public housing residents. FSS program services may include, but are not limited to child care, transportation, education, job training and employment counseling, substance/alcohol abuse treatment or counseling, household skill training, and homeownership counseling. Restrictions that discourage welfare recipients from participating in education and training as their work activity should be slackened. Welfare programs should enable parents to continue with their education as well as enroll in other training and educational programs to advance their careers. Welfare programs should provide sufficient support to allow single parents greater flexibility in regards to part-time work schedules. There also should not be a time limit on benefits while parents are working either full or part time. Welfare programs should develop better strategies for identifying and addressing the problems of families with serious barriers to employment and healthy family functioning. Those objectives should include integrating services with mental health and disabilities systems as well as creating strategic alliances with different agencies. Programs serving low-income families should remove any marriage penalties, and should provide services and benefits for the parents without reducing services and benefits for the other parents. In relates to programming is case management. There needs to be an assessment tool to assist case managers in targeting services to a heterogeneous client population. Analysis indicates that clients of case managers who used the screener, compared with a set of clients of case managers who did not use it, received more services and had higher program participation rates but experienced no improvement in short-term employment outcomes. This suggests that the instrument as a tool in case management is effective at identifying client needs, which is the first step to achieving more favorable employment-related outcomes The federal minimum wage standard is also a major issue as it relates to the income of welfare recipients. For far too long, the minimum wage level has been stagnated, leaving the economy at a stand still as well as people in poverty. Dollar for dollar, there is no better stimulus for the economy than an increase in the minimum wage.

\section{CONCLUSIONS}

Many objectives and goals have been attained with the welfare reform policy. The 1996 welfare reform legislation was one of the most successful social policy reforms in United States history. In contrast to the prior system, which rewarded idleness and dependency, reform policy made remarkable headway in helping welfare dependents move toward self-sufficiency and dramatically reduced state welfare caseloads. While the old system resulted in unwed pregnancy and a host of related social problems, welfare reforms reduced child poverty and increased employment. Because of lax enforcement and efforts to undermine the principles and goals of this reform, however, its full potential has not been realized. As our national debate continues, it is my hope that we can get past the bumper stickers and the slogans, and instead have a debate that addresses welfare policy itself in a more realistic way, placing the discussion of welfare in the context of broader issues of social, economic and racial justice. 


\section{REFERENCES}

1. Aber, J. Lawrence, Jeanne Brooks-Gunn, and Rebecca A. Maynard. Effects of Welfare Reform on Teenage Parents and Their Children. The Future of Children 5.2 Sum/Fall (1995): 53+.

2. Bavier, Richard. Welfare Reform Impacts in the SIPP: Data from the Survey of Income and Program Participation (SIPP) Suggest That Families Who Left the Rolls Due to Welfare Reform Were More Prone to Economic Difficulties Than Other Leavers, However, Income Improved for Most Post-Reform Leavers. Monthly Labor Review 125.11 (2002): 23+.

3. Besharov, Douglas J. The Past and Future of Welfare Reform. Public Interest Wntr 2003: 4+.

4. $\quad$ Cheng, Tyrone. Welfare Recipients: How Do They Become Independent? Social Work Research 26.3 (2002): $159+$.

5. Crawley, John. Welfare Reform and the Health Insurance Coverage of Women and Children Forum: Frontiers in Health Policy Research 8:5 (2005).

6. Connolly, Laura and Christine Marston. The Economic Well-bring of Children and Families after Welfare Reform Census Bureau Research Development Grants Conference (2002).

7. Edelman, Peter B. The Welfare Debate: Getting Past the Bumper Stickers. Harvard Journal of Law \& Public Policy 27.1 (2003): 93+.

8. Fang, Hanming, and Michael P. Keane. Assessing the Impact of Welfare Reform on Single Mothers. Brookings Papers on Economic Activity (2004): 1+.

9. $\quad$ Five Commentaries: Looking to the Future. The Future of Children 12.1 (2002): 187+.

10. Fuller, Bruce, Sharon L. Kagan, Gretchen L. Caspary, and Christiane A. Gauthier. Welfare Reform and Child Care Options for Low-Income Families. The Future of Children 12.1 (2002): 97+.

11. Gainsborough, Juliet F. To Devolve or Not to Devolve? Welfare Reform in the States. Policy Studies Journal 31.4 (2003): 603+.

12. Grogger, Jeffrey and Lynn A. Karoly. Welfare Reform: Effects of a Decade of Change. 2005.

13. Henman, Paul, and Julia Perry. Welfare Dependency? A Critical Analysis of Changes in Welfare Recipient Numbers. Australian Journal of Social Issues 37.3 (2002): 315+..

14. Henman, Paul. Myths of Welfare Reform. Australian Journal of Social Issues 37.1 (2002): 71+.

15. Kandula, Namratha R., Grogan, Colleen M., Rathouz, Paul J. \& Lauderdale, Diane S. The Unintended Impact of Welfare Reform on the Medicaid Enrollment of Eligible Immigrants Health Services Research. 39:5 (2004): 1509-1526.

16. Kikas, Gabriel. Bush and Booker T. Washington's 'Compassionate Conservatism'. Contemporary Review Sept. 2004: 157+.

17. Kimble, Lionel. Welfare Reform and the Revitalization of Inner City Neighborhoods. The Journal of African American History 90.1-2 (2005): 178+.

18. Lens, Vicki. Public Voices and Public Policy: Changing the Societal Discourse on "Welfare". Journal of Sociology \& Social Welfare 29.1 (2002): 137+.

19. Levine, P. and D. Whitmore. The Impact of Welfare Reform on the AFDC Caseload Wellesley College, November 1998.

20. Lichter, Daniel T. and Rukamalie Jayakody. Welfare Reform: How Do We Measure Success Annual Review of Sociology. (2002). 28:117-141.

21. Macdonald, Fredrick F. Social Welfare Reform and Employment: Is It Working?. Annals of the American Psychotherapy Association 5.6 (2002): 31.

22. Matthewson, Donald J. Welfare Reform and Comparative Models of Bureaucratic Behavior: Budget Maximizers and Bureau Shapers in the United States and France The American Review of Public Administration. 26:2 (1996): 135-158.

23. Mead, Lawrence M. State Political Culture and Welfare Reform. Policy Studies Journal 32.2 (2004): 271+.

24. O'Connor, Brendon. Policies, Principles, and Polls: Bill Clinton's Third Way Welfare Politics 1992-1996. The Australian Journal of Politics and History 48.3 (2002): 396+.

25. Price, Charles. Reforming Welfare Reform Postsecondary Education Policy: Two State Case Studies in Political Culture, Organizing, and Advocacy. Journal of Sociology \& Social Welfare 32.3 (2005): 81+.

26. Rodgers, Harrell. Welfare Reform: Making Work Really Work. Policy Studies Journal 31.1 (2003): 89+. 
27. Scheoni, R. and R. Blank. What Has Welfare Reform Accomplished? Impacts on Welfare Participation, Employment, Income, Poverty, and Family Structure NBER Working Paper \#7627, March 2000.

28. Schorr, Alvin L., Welfare Reform: Failures and Remedies. Journal of Sociology \& Social Welfare 29.4 (2002): $177+$.

29. Tweedie, Jack. Welfare Reform: Doing Well, Trying to Do Better; Welfare Reforms Have Been Quite Successful, but There's Much More to Do. Moving Ahead in Tight Budget Times, However, Is a Daunting Task for Lawmakers. State Legislatures Jan. 2003: 28+.

30. Zedlewski, Sheila Rafferty. Family Economic Resources in the Post-Reform Era. The Future of Children 12.1 (2002): $121+$.

\section{NOTES}

